\title{
CONSTRUÇÃO DE UMA MÁXIMA PROTEÇÃO JURISDICIONAL DO MEIO AMBIENTE
}

CONSTRUCTION OF MAXIMUM JURISDICTIONAL PROTECTION OF THE ENVIRONMENT

CONSTRUCCIÓN DE UNA MÁXIMA PROTECCIÓN JURISDICCIONAL DEL MEDIO AMBIENTE

\section{Jônatas Luiz Moreira de Paula1}

\section{Bruno Smolarek Dias²}

Licença CC BY:

Artigo distribuído sob os termos Creative Commons, permite uso e distribuição irrestrita em qualquer meio desde que o autor credite a fonte original.

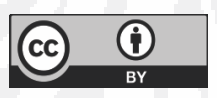

Resumo: A preocupação com o fenômeno do aquecimento global impôs ao Poder Judiciário um árduo trabalho de efetivação de normas protetivas do meio ambiente. Para tanto, urge a necessidade de constituir uma gama de regras processuais que permitem atingir tal intento. $O$ conjunto dessas regras processuais denomina-se Princípio da Máxima Proteção Jurisdicional do Meio Ambiente.

Palavras-chave: Direito Ambiental; Processo Civil; Efetivação da proteção.

Abstract: Concern about the phenomenon of global warming has imposed on the Judiciary an arduous work to enforce protective norms of the environment. To this end, it is necessary to establish a range of procedural rules that will enable this to be achieved. This set of procedural rules is called the Principle of Maximum Jurisdictional Protection of the Environment.

Key words: Environmental Law; Civil Procedure; Effectiveness of protection.

Resumen: La preocupación con el fenómeno del calentamiento global impuso al Poder Judiciario un arduo trabajo de efectivización de normas proteccionistas del medio ambiente. Para tanto, urge la necesidad de constituir una gama de reglas procesuales que permitan alcanzar tal intento. El conjunto de estas reglas procesuales se denomina Principio de la Máxima Protección Jurisdiccional del Medio Ambiente.

Palabras-clave: Derecho Ambiental; Proceso Civil; Efectuación de la protección

1 Pós-Doutor em Direito (Universidade de Coimbra), Doutor (UFPR), Mestre (UEL). Professor Titular da UNIPAR. Advogado. E-mail: jlmp@prof.unipar.br

2 Doutor em Ciência Jurídica (UNIVALI), Doutor em Diritto Publico (UNIPG - Perugia, Itália), Mestre em Direito (PUC-PR). Professor Titular da UNIPAR e UNIOESTE. Advogado. E-mail: professorbruno@prof.unipar.br 


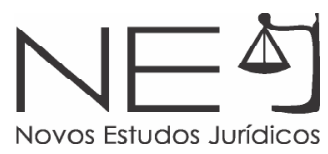

INTRODUÇÃO

Em virtude dos fundamentos políticos, sociais e econômicos que primam por um meio ambiente equilibrado e sadio, acrescido ainda pelo "despertar" da consciência ecológica decorrente dos anúncios do IPCC (Painel Intergovernamental sobre Mudanças Climáticas, em sua tradução para o português) acerca do aquecimento global, verificou-se a necessidade de uma integral proteção do meio ambiente ${ }^{3}$.

É verdade que, num passado recente, essa proteção adveio desde o Código Florestal de 1965; com a Lei $n^{\circ}$ 6.938/1981 que instituiu a Política Nacional do Meio Ambiente e do SISNAMA; também o mesmo se pode dizer da Constituição Federal de 1988, cujo artigo 225 elevou o meio ambiente sadio e equilibrado à categoria dos Direitos Fundamentais, bem como o inseriu como um princípio a ser respeitado e harmonizado na ordem econômica (art.170, VI); ou ainda em decorrência da Lei dos Crimes Ambientais (Lei n 9.605/1998); consolidada com o Novo Código Florestal por meio da Lei n 12.651, de 2012.

Mas o que se observa é que a proteção ambiental ganhou dimensão jurídica em atitudes que devem ser praticadas pelo Poder Executivo, por meio de seus diversos órgãos, mas centralizando-se em torno do Ministério do Meio Ambiente e de seus órgãos autárquicos (IBAMA ${ }^{4}$ e ICMBio ${ }^{5}$ ); pelo Poder Legislativo, por meio de legislação e fiscalização dos órgãos públicos; e pelo Ministério Público, ao atuar na fiscalização dos atos relacionados ao meio ambiente, inclusive com a instauração de inquéritos civis e ajuizamento de ações que visam responsabilizar o poluidor.

Ao Poder Judiciário, o que the restou? A despeito de sempre haver um comportamento suprapolítico a fim de garantir a sua imparcialidade frente às demandas sociais, ao Poder Judiciário resta-lhe o papel da última linha de defesa da proteção ambiental dentro das regras democráticas ${ }^{6}$.

3 DIAS, Bruno Smolarek; MARDEGAN, Herick. Sustentabilidade como fundamento da cidadania transnacional. Revista Eletrônica Direito e Política, Programa de Pós-Graduação Stricto Sensu em Ciência Jurídica da UNIVALI, Itajaí, v.6, n.2, $2^{\circ}$ quadrimestre de 2011. Disponível em: www.univali.br/direitoepolitica - ISSN 1980-7791 Instituto Brasileiro do Meio Ambiente e dos Recursos Naturais Renováveis. Instituto Chico Mendes de Conservação da Biodiversidade.

PIASSA, Felipe José; DIAS, Bruno Smolarek. Influências pós-positivistas ao novo direito constitucional e o fenômeno da constitucionalização do direito. Revista Eletrônica Direito e Política, Programa de Pós-Graduação Stricto Sensu em Ciência Jurídica da UNIVALI, Itajaí, v.10, n.3, $2^{\circ}$ quadrimestre de 2015. Disponível em: www. univali.br/direitoepolitica - ISSN 1980-7791 
A melhor maneira de operacionalizar essa conduta jurisdicional é instituir um princípio-matriz que orienta todo o desenvolvimento da relação processual em demandas ambientais, a partir de institutos processuais próprios e aplicáveis setorialmente. Acredita-se que este princípio já existe e apenas compete revelálo. É o Princípio da Máxima Proteção Jurisdicional do Meio Ambiente.

\section{CONCEITO}

A Máxima Proteção Jurisdicional do Meio Ambiente consiste num conjunto de técnicas processuais destinadas a assegurar o desenvolvimento válido da relação processual apta a permitir o reconhecimento da existência de uma poluição ou degradação ambiental ${ }^{7}$ e assim permitir a concessão da tutela jurisdicional apta e específica para eliminar a ilicitude ou o dano ambiental provocado pelo poluidor?.

Esse princípio possui a árdua tarefa de, simultaneamente, permitir a inserção de técnicas processuais que instrumentalizam a proteção jurisdicional do meio ambiente, sem que se abra mão de condições de validade do processo, a fim de conquistar a devida efetividade processual ${ }^{9}$.

Esse princípio apresenta duas dimensões: a procedimental e a instrumental. Será dimensão procedimental aquela que atua quanto à instauração e ao desenvolvimento da relação processual. Por outro lado, a dimensão instrumental vê a relação processual no plano de realização e na efetivação de direitos.

\section{DIMENSÃO PROCEDIMENTAL}

Na dimensão procedimental, o Princípio da Máxima Proteção Jurisdicional do Meio Ambiente propõe a ampliação da legitimidade ativa para as ações ambientais, usualmente coletivas em sua essência, a fim de que se possa conferir

7 De acordo com a Lei $n^{\circ} 6.938 / 1981$, artigo $3^{\circ}$, inciso II, respectivamente, entende-se por degradação da qualidade ambiental a alteração adversa das características do meio ambiente; e no inciso III define-se por poluição a degradação da qualidade ambiental resultante de atividades que direta ou indiretamente: a) prejudiquem a saúde, a segurança e o bem-estar da população; b) criem condições adversas às atividades sociais e econômicas; c) afetem desfavoravelmente a biota; d) afetem as condições estéticas ou sanitárias do meio ambiente; e) lancem matérias ou energia em desacordo com os padrões ambientais estabelecidos.

8 Também de acordo com a Lei $n^{\circ} 6.938 / 1981$, artigo $3^{\circ}$, IV, entende-se por poluidor a pessoa física ou jurídica, de direito público ou privado, responsável, direta ou indiretamente, por atividade causadora de degradação ambiental.

9 BOSSELMANN, Klaus. The Principle of Sustainability: Transforming Law and Governance. Hampshire, England: Ashgate, 2008. 
ao indivíduo a titularidade do exercício da ação, bem como a inexistência de litispendência entre a ação individual e a ação coletiva, e a facilitação para o acesso à justiça com a isenção das custas e das despesas processuais.

\subsection{A QUESTÃO DA LEGITIMAÇÃO ORDINÁRIA}

Sabe-se muito bem a legitimação para as ações ambientais das instituições públicas, principalmente ao Ministério Público, aos órgãos públicos (como as autarquias ambientais), à Defensoria Pública e às associações não governamentais (ONGs), visando melhor tutelar os interesses coletivos e difusos envolvidos na lide ambiental.

É definida classicamente como legitimidade extraordinária, eis que o legitimado atua em nome próprio para tutelar direito alheio (difuso ou coletivo). Em termos práticos, significa que o legitimado para ação ambiental assim atua por não sofrer com os efeitos da poluição/degradação ambiental em razão de autorização legal. Todavia essa é uma diretiva jurídica e não uma exclusividade a ponto de eliminar a possibilidade do indivíduo em promover a ação ambiental quando a degradação ambiental/poluição lhe afetar diretamente. Cumpre, ainda, destacar para efeitos de compreensão deste trabalho que se considera apenas para efeito de uma típica lide ambiental a ação em que se discute na causa de pedir a existência ou a ameaça de degradação ambiental/poluição, e o pedido de tutela jurisdicional que visa debelar essa ameaça ou reparar pelo modo específico essa degradação ambiental/poluição.

Portanto a legitimidade do indivíduo para promover a ação ambiental não se justifica na existência de danos materiais a serem indenizados, mas na própria condição de vítima da degradação ambiental ou da poluição. Promover uma ação visando à indenização por danos materiais a partir da degradação ambiental/poluição seria considerada uma ação informada pelo direito obrigacional e não uma típica ação ambiental. O que se pretende aqui é justificar a legitimidade ordinária do indivíduo a promover a ação ambiental na condição de vítima da degradação ambiental/poluição. Trata-se de um conceito material, isto é, da pessoa física que se enquadre nalguma

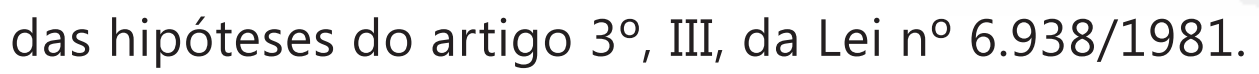


Por isso o indivíduo, quando promove a ação ambiental, assim o faz porque se encontra inserido numa relação ambiental, da qual é vítima de poluição. Daí extrair a possibilidade jurídica de, em nome próprio, agir para tutela direito próprio - isto é, livrar-se de uma atividade poluente ${ }^{10}$. Nessa linha de entendimento, o STJ manifestou a possibilidade da ação individual ambiental quando o autor surge como vítima da poluição ${ }^{11}$, de tal sorte a proteção ambiental não decorre necessária e exclusivamente por iniciativa dos legitimados extraordinários.

\subsection{A INEXISTÊNCIA DE LITISPENDÊNCIA ENTRE A AÇÃO INDIVIDUAL E A AÇÃO COLETIVA}

Como o nome indica (litis + pendência), a litispendência é a existência simultânea de duas ou mais ações idênticas. Para que haja ações idênticas, é preciso haver identidade de partes, de causa de pedir e de pedido, consoante estipula os $\S \S 1^{\circ}, 2^{\circ}$ e $3^{\circ}$ do artigo 337 do CPC. Exemplo típico de litispendência é a ação de rescisão de contrato cumulado com perdas e danos, em que existirão duas ações que terão as mesmas partes (contratantes), a mesma causa de pedir (infração contratual) e os mesmos pedidos (desconstituição da relação contratual e a indenização por perdas e danos decorrentes da infração ao contrato).

A litispendência pode ser expressa, como no exemplo anterior, mas pode ocorrer de forma embutida em outro pedido, como entre uma ação autônoma e a reconvenção proposta em virtude de outro processo - neste caso, haverá litispendência entre a ação e a reconvenção; ou de forma implícita, quando, em dois processos com as mesmas partes, o réu propõe reconvenção em ambos os processos, deduzindo a mesma causa de pedir e o mesmo pedido - neste caso, a litispendência surge entre as reconvenções. Em termos ambientais se questiona acerca da ocorrência de litispendência entre a ação coletiva e a ação individual, que incidam sobre a mesma causa de pedir e pedido. Acredita-se que, pela negativa e ocorrendo tal situação, deve-se aplicar a regra processual da reunião de processos em torno do juízo prevento em virtude da incidência da conexão (CPC, art. 55). São vários os motivos para tanto. Ei-los.

10 PAULA, Jônatas Luiz Moreira de. Aspectos da tutela individual ambiental. Revista de Processo. Volume 145. Ano 32. Março 2007. São Paulo: Revista dos Tribunais, 2007, p. 62-63.

11 AREsp 865768, rel. Min. Luis Felipe Salomão, p. 29/03/2016; e AREsp 414130, rel. Min. Antonio Carlos Ferreira, p. 09/12/2013. 
Inicialmente, deve-se consignar que não há identidade de autores entre a ação coletiva e a ação individual, embora o réu possa ser o mesmo. Além disso, por causa da ausência de identidade de autores, há que se constatar também que, na ação coletiva, o legitimado extraordinário busca diretamente a tutela de interesse alheio (difusos, coletivos ou individuais homogêneos), ao passo que o legitimado ordinário busca diretamente a tutela de interesse próprio, ainda que eficácia subjetiva da sentença possa beneficiar terceiros.

Logo, impor a litispendência na concorrência de ações que visam proteger o meio ambiente, ainda que haja identidade de réu, de causa de pedir e de pedido, seria negar ao legitimado - extraordinário ou ordinário - o constitucional direito de acessar a justiça, além de negar vigência ao artigo 225, caput, da CF, quando prevê que é dever dos poderes públicos e da sociedade a proteção do meio ambiente ${ }^{12}$.

Por esse motivo, decidiu corretamente o TJPR que a propositura da ação individual, quando já se encontrava em curso ação civil pública com os mesmos pedidos e causa de pedir, não caracteriza litispendência, porque o direito de ação, constitucionalmente assegurado $\left(C F\right.$, art. $\left.5^{\circ}, X X X V\right)$, não pode ser obstado pelo interesse público ou coletivo ${ }^{13}$. Ou como pronunciou o STJ em diversas vezes, a circunstância de existir ação coletiva em que se objetiva a tutela de direitos individuais homogêneos não obsta a propositura da ação individual14.

Todavia, os últimos entendimentos mostram a possibilidade de suspender ação individual ajuizada quando se encontrava em curso ação coletiva, tendo nesta a macro-lide que repercute na ação individual. Neste caso, visível a conexão de causas. É a decisão do TJPR que bem sintetiza essa técnica:

AGRAVO DE INSTRUMENTO. AÇÃOINDIVIDUAL DE REPARAÇÃO DEDANOS MORAIS DECORRENTES DE DANOS AMBIENTAIS. CONTAMINAÇÃO DE METAIS PESADOS NA REGIÃO DO ALTO DO VALE DO RIBEIRA (PR). DECISÃO AGRAVADA QUE DETERMINA A SUSPENSÃO DA AÇÃO. INSURGÊNCIA DA PARTE AUTORA. NÃO ACOLHIMENTO. EXISTÊNCIA DE AÇÃO COLETIVA QUE VERSA SOBRE A MESMA PRETENSÃO DE DIRETTO INDIVIDUAL HOMOGÊNEO. CONTROVÉRSIA MULTITUDINÁRIA. POSSIBILIDADE DE SUSPENSÃO, DE

12 PAULA, Jônatas Luiz Moreira de. O Devido Processo Legal Ambiental. In: Direito Ambiental e Cidadania. Jônatas Luiz Moreira de Paula (coord.). Leme: JH Mizuno, 2007, p. 106-107.

13 Apel. Civ. e Reex. Nec. $n^{\circ} 0069498-4,1^{\text {a }}$ CCiv., rel Des. Sidney Zappa, j. 03/11/1998.

14 RESP n 640071/PE, $2^{\text {a }}$ T., rel. Min. Franciulli Netto, j. 19/08/2004; RESP nº 153750/PE, $3^{\text {a }}$ T., rel. Min. Carlos Alberto Menezes Direito, j. 03/02/2000; RESP nº 147473, 3ª T, rel. Min. Eduardo Ribeiro, j. 15/12/1997. 
OFÍCIO, DA AÇÃO INDIVIDUAL, MESMO ANTES DA CITAÇÃO DA PARTE RÉ, ATÉ O JULGAMENTO DEFINITIVO DA AÇÃO COLETIVA.PRECEDENTES. 1. 'Ajuizada ação coletiva atinente a macro lide geradora de processos multitudinários, suspendem-se as ações individuais, no aguardo do julgamento da ação coletiva' (STJ, Resp. 1.110.549/RS, Rel. Ministro Sidnei Beneti, Dj. 28.10.2009); 2. A suspensão da ação previamente à citação da parte ré não acarreta prejuízo às partes, seja no que se refere à interrupção da prescrição, que retroage à data da propositura da demanda (CPC, art.219, $\left.\S 1^{\circ}\right)$, seja ante a possibilidade de convolação da ação individual em cumprimento de sentença, caso a demanda coletiva seja benéfica ao autor, seja porque, no caso de condenação da parte ré, os juros moratórios incidirão desde a data do evento danoso (STJ, Súmula 54); 3. A determinação da suspensão da ação individual decorre de norma especial, prevista no art. 104 do Código de Defesa do Consumidor, que não faz qualquer limitação ao prazo de suspensão. DECISÃO MANTIDA. RECURSO CONHECIDO E NÃO PROVIDO ${ }^{15}$.

Preservando-se as ações, há que se reconhecer a conexão entre elas e, consequentemente, a racionalidade na produção de provas, que deverá ser integrada, como o uso de prova emprestada, sobretudo a pericial, sob a égide da eficiência e da economia processual. Ademais, a preservação das ações que surgem em razão da mesma questão ambiental realça a eficácia do Princípio da Participação do cidadão, que é elementar para o Direito Ambiental. Por fim, o artigo 104, primeira parte, do CDC, estipula expressamente que não haverá litispendência entre a ação individual e a ação coletiva, o que refuta de vez a tese pela admissibilidade.

Divergia em parte desse posicionamento, e certamente na pretensão de conferir a univocidade da tutela jurisdicional, o Anteprojeto de Código Brasileiro de Processos Coletivos, ao prever a admissão da ocorrência de litispendência quando houver conexão e continência entre ações coletivas (art. $6^{\circ}, \S^{\circ}$ ). Mas não admitira a litispendência entre a ação coletiva e a ação individual "em que sejam postulados direitos ou interesses próprios e específicos de seus autores" (art. $7^{\circ}$ ), mas deverá o juiz comunicar ao Ministério Público a existência de pluralidade de ações, tendo o mesmo o réu e o mesmo fundamento jurídico, a fim de que seja proposta a ação coletiva (art. $8^{\circ}$ ).

O referido Anteprojeto foi modificado por Proposta de Anteprojeto da Lei de Ação Civil Pública e mantém a possibilidade de litispendência entre as ações coletivas (art. $7^{\circ}$ da proposta) e nega a admissibilidade da litispendência entre a 15 A.I. $n^{\circ} 1366668-1,8^{a}$ CCiv., rel. Des. Francisco Eduardo Gonzaga de Oliveira, j. 17/09/2015. 
ação coletiva e a ação individual (art. $8^{\circ}$ da proposta), mantendo-se o dever de comunicação ao Ministério Público acerca das demandas individuais (art. 19). Interessante que no art. $21, \S 5^{\circ}$, II, da proposta legislativa, deverá o juiz, no momento do saneador, "separar os pedidos em ações coletivas distintas, voltadas à tutela, respectivamente, dos interesses ou direitos difusos e coletivos, de um lado, e dos individuais homogêneos, do outro, desde que a separação represente economia processual ou facilite a condução do processo".

Igualmente se houve bem a Presidência da República ao vetar o artigo 333 do Novo CPC, quando esse previa a possibilidade de se converter ações individuais em ação coletiva, gerando a extinção daquelas ${ }^{16}$. O fundamento para tal veto é de que tal conversão iria significar na negação do constitucional acesso à justiça, ainda mais quando o autor já havia promovido a ação e instaurada a relação processual. Assim,

16 Art. 333. Atendidos os pressupostos da relevância social e da dificuldade de formação do litisconsórcio, o juiz, a requerimento do Ministério Público ou da Defensoria Pública, ouvido o autor, poderá converter em coletiva a ação individual que veicule pedido que:

I - tenha alcance coletivo, em razão da tutela de bem jurídico difuso ou coletivo, assim entendidos aqueles definidos pelo art. 81, parágrafo único, incisos I e II, da Lei n 8.078, de 11 de setembro de 1990 (Código de Defesa do Consumidor), e cuja ofensa afete, a um só tempo, as esferas jurídicas do indivíduo e da coletividade;

II - tenha por objetivo a solução de conflito de interesse relativo a uma mesma relação jurídica plurilateral, cuja solução, por sua natureza ou por disposição de lei, deva ser necessariamente uniforme, assegurando-se tratamento isonômico para todos os membros do grupo.

$\S 1^{\circ}$ Além do Ministério Público e da Defensoria Pública, podem requerer a conversão os legitimados referidos no art. $5^{\circ}$ da Lei $n^{\circ} 7.347$, de 24 de julho de 1985, e no art. 82 da Lei n 8.078, de 11 de setembro de 1990 (Código de Defesa do Consumidor).

$\S 2^{\circ} \mathrm{A}$ conversão não pode implicar a formação de processo coletivo para a tutela de direitos individuais homogêneos.

$\S 3^{\circ}$ Não se admite a conversão, ainda, se:

I - já iniciada, no processo individual, a audiência de instrução e julgamento; ou

II - houver processo coletivo pendente com o mesmo objeto; ou

III - o juízo não tiver competência para o processo coletivo que seria formado.

$\S 4^{\circ}$ Determinada a conversão, o juiz intimará o autor do requerimento para que, no prazo fixado, adite ou emende a petição inicial, para adaptá-la à tutela coletiva.

$\S 5^{\circ}$ Havendo aditamento ou emenda da petição inicial, o juiz determinará a intimação do réu para, querendo, manifestar-se no prazo de 15 (quinze) dias.

$\S 6^{\circ} \mathrm{O}$ autor originário da ação individual atuará na condição de litisconsorte unitário do legitimado para condução do processo coletivo.

$\S 7^{\circ} \mathrm{O}$ autor originário não é responsável por nenhuma despesa processual decorrente da conversão do processo individual em coletivo.

$\S 8^{\circ}$ Após a conversão, observar-se-ão as regras do processo coletivo.

$\S 9^{\circ}$ A conversão poderá ocorrer mesmo que o autor tenha cumulado pedido de natureza estritamente individual, hipótese em que o processamento desse pedido dar-se-á em autos apartados.

§ 10. O Ministério Público deverá ser ouvido sobre o requerimento previsto no caput, salvo quando ele próprio o houver formulado. 
Novos Estudos Jurídicos

acredita-se na inadmissibilidade da litispendência entre a ação individual e a ação coletiva para fins de proteção ambiental em vista da expansão da legitimidade para a proteção ambiental.

\subsection{A ISENÇÃO DE CUSTAS E DESPESAS PROCESSUAIS}

Outro aspecto procedimental é a gratuidade das custas e das despesas processuais e a isenção dos honorários advocatícios. Essa gratuidade deve ocorrer independentemente da condição de miserabilidade do autor da ação, como poderia ser exigida nas ações ambientais individuais. Ela deve ocorrer nos moldes da ação popular, eis que, inexistindo má-fé do autor, a demanda se destina a proteger um Direito Fundamental. Portanto não há que se falar em assistência judiciária gratuita, posto que o autor da ação ambiental pode ser uma pessoa hiperssuficiente economicamente. Mas a gratuidade decorre da natureza do objeto a ser suscetível de proteção jurisdicional: a tutela do meio ambiente.

\section{DIMENSÃO INSTRUMENTAL}

Na dimensão instrumental, o Princípio da Máxima Proteção Jurisdicional do Meio Ambiente propõe a fungibilidade da causa de pedir e do pedido, reitera a inversão do ônus da prova e a tutela específica na sentença, bem como a possibilidade de relativizar a coisa julgada.

\subsection{FUNGIBILIDADE DA CAUSA DE PEDIR E DO PEDIDO}

No que se refere à fungibilidade da causa de pedir e do pedido, preliminarmente cumpre destacar que se trata de um tema polêmico, em que a imensa maioria da doutrina processual não admite. Todavia, ousadamente se busca estabelecer postulados para a sua admissibilidade. Isso porque a fungibilidade da causa de pedir e do pedido tem como objetivo a possibilidade de conciliação da ação ambiental com a situação fática que exige proteção jurisdicional ${ }^{17}$. Assim, pelo fato de o meio ambiente referir-se a um Direito Fundamental que serve de piso vital mínimo para o ser humano, não se deve aplicar a teoria da substanciação da causa de pedir, mas, isto sim, a teoria da individualização (ou individuação) ${ }^{18}$. 
Por esta teoria, a tutela jurisdicional emergirá a partir do Direito Fundamental a um meio ambiente sadio e equilibrado que é ofendido ante uma situação fática descrita na inicial. Caso a situação descrita na inicial não encontre amparo nas provas, mas, por outro lado, essas mesmas provas demonstrem que outra situação fática está a ofender o meio ambiente sadio e equilibrado, admite-se a fungibilidade automática da causa de pedir para prosseguir a demanda no reconhecimento da ilicitude e do dano ambiental que ora se apresenta. Isso porque, de todo modo, está havendo uma ofensa (lesão ou ameaça) ao Direito Fundamental ao meio ambiente sadio e equilibrado, que igualmente atenta contra o piso vital mínimo para o ser humano existir e desenvolver, tanto pessoal, como social, como também economicamente. Ou seja, de todo modo persiste o conceito de poluição/degradação ambiental praticado pelo mesmo réu e reconhecido no mesmo processo. É o exemplo de uma ação que narra uma poluição gerada por emissão de gases de uma empresa. Realizada a prova pericial, verifica-se que o grau de toxicidade do gás está dentro dos padrões ambientais admitidos, contudo também se verifica que a empresa está despejando fluidos tóxicos em um rio em níveis acima dos padrões ambientais aceitáveis, resultando em poluição. Neste caso, é indiferente haver poluição atmosférica ou da água, pois de todo modo persiste o elemento contaminante nos recursos naturais ${ }^{19}$ que são protegidos pelo Direito Ambiental.

Note-se que a admissibilidade da fungibilidade da causa de pedir nas ações ambientais encontra um respaldo técnico: seja qual for ou como se deu a ofensa (lesão ou ameaça) ao meio ambiente, sempre haverá presença do conceito de degradação ambiental estipulado no artigo $3^{\circ}$, II, da Lei nº 6.938/1981 (alteração adversa das características do meio ambiente) ou o conceito de poluição, também estipulado no artigo $3^{\circ}$, III, da Lei n 6.938/1981 (degradação da qualidade ambiental resultante de atividades que direta ou indiretamente: a) prejudiquem a saúde, a segurança e o bem-estar da população; b) criem condições adversas às atividades sociais e econômicas; c) afetem desfavoravelmente a biota; d) afetem as condições estéticas ou sanitárias do meio ambiente; e) lancem matérias ou energia em desacordo com os padrões ambientais estabelecidos).

19 De acordo com a Lei $n^{\circ} 6.938 / 1981$, artigo $3^{\circ}$, V, são recursos ambientais: a atmosfera, as águas interiores, superficiais e subterrâneas, os estuários, o mar territorial, o solo, o subsolo, os elementos da biosfera, a fauna e a flora. 
Igualmente, pode-se notar que, qual seja a causa da ofensa (lesão ou ameaça) também sempre implicará uma alteração do meio ambiente que, por disposição constitucional, deve ser sadio e equilibrado (art. 225, caput).

Esse fenômeno que permite a fungibilidade ocorre nas chamadas causa de pedir normatizada, ou seja, aquelas cuja fundamentação fática devem sempre se adequar às hipóteses especificadamente tipificadas em lei. Situação semelhante ocorre, por exemplo, na ação em que pede alimentos, cujo autor afirma a necessidade em virtude de necessidades básicas, porém se identifica no curso processo da necessidade de um tratamento médico excepcional.

Também é o que se pode afirmar no caso de averiguação do abuso do poder político ou do poder econômico, para fins de inelegibilidade, nos termos do art. 22 da Lei Complementar n 64/1990. Pode-se imaginar uma ação em que se denuncia a concessão de dinheiro a eleitores, quando na instrução se verifica que houve a promessa indiscriminada de futuras contratações com promessas e nomeações de cargos com o nítido objetivo de captação indevida de sufrágio. De todo modo, mostra-se procedente a investigação judicial eleitoral, pois se comprovou o abuso do poder econômico ou político.

Ou nos casos de improbidade administrativa, regidos pela Lei n 8.429/1992, em que se acusa o réu de ter recebido vantagem econômica mediante recebimento numa quantia em dinheiro, todavia a instrução revela que ela se deu por dação de bens imóveis. Nesse aspecto, permanece o conceito jurídico de improbidade administrativa que importa em enriquecimento ilícito (art. $9^{\circ}$ ).

Pode-se ainda imaginar ainda o ajuizamento de uma ação civil pública pleiteando a nulidade do edital de licitação da construção de uma obra por ausência de licença prévia e, durante o seu trâmite, verifica-se que os valores apontados para a obra se encontram superfaturados. Assim, pode-se imaginar que a ação é procedente e o edital será declarado nulo, em vista dos valores superfaturados, mesmo que a licença prévia tenha sido expedida.

Igualmente é lícito cogitar na fungibilidade da causa de pedir nas ações previdenciárias, quando se verificar a possibilidade de concessão de um melhor 
benefício em relação ao que fora requerido inicialmente, se preenchidos os requisitos para tanto e esses benefícios forem aposentadoria por invalidez ou auxílio-doença. Isso porque, entre esses benefícios, há um núcleo temático comum: a exigência da incapacidade laboral do autor da demanda. Em tais casos verifica-se "certa margem de manobra" da exposição dos fatos na causa de pedir, a fim de que ela se amolde à proteção jurídica invocada. Na prática, observa-se a existência da fungibilidade da causa de pedir. Isso é inegável.

Ademais, em vista da amplitude dos Princípios do Acesso à Justiça (CF, art. $5^{\circ}$, XXXV e CPC, art. $3^{\circ}$ ) e do Devido Processo Legal (CF, art. 50, LIV) e dos fins sociais do processo civil (CPC, art. $8^{\circ}$ ), há que se reconhecer que no desenvolvimento do processo e na composição da tutela jurisdicional a possibilidade da fungibilidade da causa de pedir, sem que isso incorra em sentença infra, extra ou ultra petita, como prevê o art. 492 do $\mathrm{CPC}^{20}$, pois há que se proteger o interesse público por meio da tutela jurisdicional adequada ao caso concreto. A indisponibilidade do direito impõe a necessidade da adequada e específica tutela jurisdicional protetiva.

Consequentemente, com a fungibilidade da causa de pedir na ação ambiental, admitir-se-á também a fungibilidade da tutela jurisdicional pleiteada na inicial. Isso é um efeito decorrente da própria fungibilidade da causa de pedir e se destina a conformar-se à situação fática que exige de forma adequada e específica a remoção do ilícito ou do dano ambiental. Assim, por exemplo, se na ação está descrita uma situação de ameaça de degradação ambiental e por isso se requer uma tutela inibitória consistente numa prestação de não fazer, e durante o processo se constata a presença do dano ambiental, haverá a conversão tanto da causa de pedir (de ameaça para dano), como também da tutela jurisdicional (de uma tutela inibitória para uma tutela reintegratória do direito), eis que a prestação de não fazer mostra-se inadequada para a remoção do dano ambiental, devendo, por isso, ser imposto ao réu uma prestação de fazer (restaurar o meio ambiente).

A conversão de tutela jurisdicional nas demandas ambientais obedece, como explicitado, à busca da tutela adequada e específica para remover o ilícito ou

20 Art. 492. É vedado ao juiz proferir sentença de natureza diversa da pedida, bem como condenar a parte em quantidade superior ou em objeto diverso do que lhe foi demandado. Parágrafo único. A sentença deve ser certa, ainda quando decida relação jurídica condicional. 
o dano ambiental. Assim, compreende-se que essa conversão deva ocorrer no âmbito da prestação de fazer ou de não fazer a ser imputada como efeito principal ou secundário das tutelas declaratória, condenatória, constitutiva, desconstitutiva, mandamental, executiva lato sensu, executiva stricto sensu e cautelar. O efeito da fungibilidade é evitar a ocorrência de julgamentos extra ou ultra petita, eis que esses devem adequar-se ao caso concreto para melhor tutelar o meio ambiente. É o que se pode extrair do seguinte aresto do STJ:

PROCESSUAL CIVIL. ADMINISTRATIVO. AÇÃO CIVIL PÚBLICA. DANO AMBIENTAL. OCUPAÇÃO IRREGULAR DE ÁREA DE PRESERVAÇÃO PERMANENTE COM DEGRADAÇÃO AMBIENTAL. JULGAMENTO EXTRA E ULTRA PETITA. INOCORRÊNCIA. 1. A tutela ambiental é de natureza fungível por isso que a área objeto da agressão ao meio ambiente pode ser de extensão maior do que a referida na inicial e, uma vez assim aferida pelo conjunto probatório, não importa em julgamento ultra ou extra petita. 2. A decisão extra petita é aquela inaproveitável por conferir à parte providência diversa da almejada, mercê do deferimento de pedido diverso ou baseado em causa petendi não eleita. Consectariamente, não há decisão extra petita quando o juiz examina o pedido e aplica o direito com fundamentos diversos dos fornecidos na petição inicial ou mesmo na apelação, desde que baseados em fatos ligados ao fato-base. Precedentes do STJ: AgRg no REsp 1164488/DF, SEGUNDA TURMA, DJe 07/06/2010; RMS 26.276/SP, QUINTA TURMA, DJe 19/10/2009; e AgRg no AgRg no REsp 825.954/PR, PRIMEIRA TURMA, DJ de 15/12/2008. 3. Deveras, a análise do pedido dentro dos limites postos pela parte não incide no vício in procedendo do julgamento ultra ou extra petita e, por conseguinte, afasta a suposta ofensa aos arts. 460 e 461, do CPC. 4. Ademais, os pedidos devem ser interpretados, como manifestações de vontade, de forma a tornar o processo efetivo, o acesso à justiça amplo e justa a composição da lide. Precedentes do STJ: AgRg no Ag 1038295/RS, PRIMEIRA TURMA, DJe 03/12/2008; AgRg no Ag 865.880/RJ, PRIMEIRA TURMA, DJ 09/08/2007; AgRg no Ag 738.250/GO, QUARTA TURMA, DJ 05/11/2007; e AgRg no Ag 668.909/SP, QUARTA TURMA, DJ 20/11/2006; (... $)^{21}$.

Contudo, deve-se acolher a advertência de Marcelo Abelha Rodrigues: em nome da mobilidade da causa de pedir e do pedido não se pode permitir uma causa de pedir aberta, a ponto de admitir ou legalizar surpresas processuais para a defesa ${ }^{22}$.

Deve, neste caso, o interessado demonstrar a existência do fato e o juiz, em torno disso, apurar a melhor tutela jurisdicional adequada ao caso.

21 RESP n ${ }^{\circ} 1107219 / S P, 1^{\text {a }}$ T., rel. Min. Luiz Fux, j. 02/09/2010.

22 RODRIGUES, Marcelo Abelha. Processo Civil Ambiental. São Paulo: Revista dos Tribunais, 2008 p. 90-91. 
A fungibilidade da causa de pedir e do pedido ocorrerá automaticamente no processo e sempre incidirá quando for detectada a existência da poluição (Lei nº 6.938/1981, art. 30, III).

$\mathrm{Na}$ forma proposta pelo Anteprojeto do Código Brasileiro de Processos Coletivos, a fungibilidade da causa de pedir e do pedido deveria ocorrer até antes da sentença, mediante petição expondo os fatos e assegurado a ampla defesa e o contraditório, reservando-se o prazo de, ao menos, 10 (dez) dias para o contraditório, com possibilidade de prova complementar (art. $5^{\circ}$, parágrafo único). Essa sugestão está reiterada pela Proposta de Anteprojeto de Lei da Nova Ação Civil Pública (art. 18).

Na redação original apresentada, no Anteprojeto do Novo CPC no Senado Federal havia também a possibilidade da fungibilidade da causa de pedir contemplado no art. $314^{23}$. Todavia, essa proposta fora rejeitada por votações no Senado Federal e na Câmara dos Deputados e assim o Novo CPC não contemplou a fungibilidade da causa de pedir, a despeito de continuar existindo na praxe forense.

A rigor doutrinário, seria dispensável ser formulada uma petição expondo os novos fatos, em vista da compreensão de que incide na ação ambiental a teoria da individualização da causa de pedir. No entanto, há de se louvar a preocupação em assegurar a ampla defesa e o contraditório.

Também a conversão da causa de pedir e do pedido nas ações ambientais permitirá ampla incidência do efeito da translatividade no recurso de apelação. Assim, eventuais questões ambientais, merecedoras de proteção jurisdicional, poderão ser conhecidas de ofício pelo Tribunal, mesmo que a sentença recorrida ou o recurso não as tenha abordado, sempre assegurando a prévia manifestação dos interessados. É a regra dos art. 10 e 1.013, ambos do CPC.

\subsection{A INVERSÃO DO ÔNUS DA PROVA}

Outro aspecto deferido ao aspecto instrumental se dá pelo acolhimento da inversão do ônus da prova nas demandas ambientais. Pelo Novo CPC, houve melhor

23 Previa esse dispositivo: O autor poderá, enquanto não proferida a sentença, aditar ou alterar o pedido e a causa de pedir, desde que o faça de boa-fé e que não importe em prejuízo ao réu, assegurado o contraditório mediante a possibilidade de manifestação deste no prazo mínimo de quinze dias, facultada produção de prova suplementar. 
formatação normativa, eis que a inversão do ônus da prova não só se dará pela hipossuficiência econômica, como também pela hipossuficiência técnica (art. 373) ${ }^{24}$.

Ademais, o Novo CPC também estabeleceu uma regra temporal para a determinação da inversão do ônus da prova: nos termos do art. 357, ela deverá ocorrer na decisão saneadora. Por esse motivo é lícito afirmar que a inversão do ônus da prova é um encargo processual que incide sobre a atividade processual da parte, assim deixando de ser um critério de julgamento a ser manifestado quando do proferimento da sentença, gerando julgamento surpresa, o que é vedado, como se vê nos art. $9^{\circ}$ e 10.

\subsection{A TUTELA ESPECÍFICA NA SENTENÇA}

O ápice da proteção jurisdicional do meio ambiente ocorre nos momentos de julgamentos, que pode se dar na concessão de tutela provisória em razão da urgência ou não ${ }^{25}$, ou na concessão da tutela definitiva na sentença/acórdão. Em tais oportunidades processuais há uma absoluta preocupação em obter a tutela específica ambiental. Certamente há um fetichismo da jurisdição em busca da tutela específica, e obviamente isso não ocorre em vão, pois esta veneração exagerada se justifica pelos fins propositados pelo Direito Ambiental: a adequada e devida proteção ambiental.

Toda a construção da tutela ambiental na sentença passa inexoravelmente pela discricionariedade judicial. Pois, por meio dela, poder-se-á exercer o ius edictio, característico dos artigos 84 do CPC e 497 do CPC, e que muito se

24 Art. 373. O ônus da prova incumbe:

I - ao autor, quanto ao fato constitutivo de seu direito;

II - ao réu, quanto à existência de fato impeditivo, modificativo ou extintivo do direito do autor.

$\S 1$ 을 Nos casos previstos em lei ou diante de peculiaridades da causa relacionadas à impossibilidade ou à excessiva dificuldade de cumprir o encargo nos termos do caput ou à maior facilidade de obtenção da prova do fato contrário, poderá o juiz atribuir o ônus da prova de modo diverso, desde que o faça por decisão fundamentada, caso em que deverá dar à parte a oportunidade de se desincumbir do ônus que lhe foi atribuído.

§ 2ำ A decisão prevista no § 1ㅇ deste artigo não pode gerar situação em que a desincumbência do encargo pela parte seja impossível ou excessivamente difícil.

§ 3ํA distribuição diversa do ônus da prova também pode ocorrer por convenção das partes, salvo quando:

I - recair sobre direito indisponível da parte;

II - tornar excessivamente difícil a uma parte o exercício do direito.

§ 4ㅇ A convenção de que trata o § 3ㅇ pode ser celebrada antes ou durante o processo.

25 Geralmente em decisões interlocutórias, porque o art. 1.012, $\S 1^{\circ}$, V, permite inferir que a sentença pode conceder tutela provisória. 


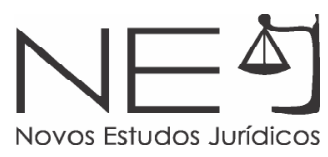

assemelha ao injunction do sistema norte-americano. Sempre se deve relembrar que o artigo 84 do CDC se aplica às demandas que versem sobre interesses difusos, coletivos ou individuais homogêneos; ao passo que o artigo 497 do CPC é manejado para demandas que versem sobre interesses estritamente individuais. Todavia, o conteúdo dessas normas processuais se concilia, eis que visa regular situações fáticas em que não há um prévio modelo normativo que o discipline.

Para Fiorillo, a aplicação do artigo 84 do CDC possibilita uma execução específica e que foge do modelo tradicional do Direito Civil, pouco afeito às questões de contrato de massa, porque, ante a inadimplência, há uma tendência à conversão em perdas e danos ${ }^{26}$. É a luta para se evitar a responsabilidade monetizada do meio ambiente degradado. A tutela específica ambiental é voltada para impedir a prática, a repetição ou a continuação do ilícito, bem como para a remoção de um ato ilícito de eficácia continuada, podendo estas estar ou não associadas à produção de um dano. A tutela específica ambiental, sob a inspiração em Marinoni ${ }^{27}$, pode ser a Reintegratória e a Inibitória. Concebe-se tutela reintegratória à espécie de tutela jurisdicional específica que tem por objetivo remover a causa da ilicitude ou do dano ambiental. Caso haja interesse em reparar patrimonialmente os danos ocorridos pela poluição, deve-se buscar uma tutela ressarcitória, e mesmo que busque a condenação do poluidor ao pagamento da multa ambiental, ter-se-á a tutela ressarcitória pelo equivalente ao valor do custo necessário para a reparação na forma específica nos termos do artigo 13 da Lei no 7.347/1985. Em tais casos, a tutela ressarcitória pelo viés monetário não visa imediatamente reparar o meio ambiente degradado, razão pela qual não se classifica como tutela específica ambiental.

Tem-se por tutela inibitória como espécie de tutela preventiva, com vistas a prevenir a ocorrência do ilícito. Assim, a tutela inibitória se apresenta como uma tutela anterior à prática do ilícito e não como uma tutela voltada para o passado, como a tradicional tutela ressarcitória. Isso significa que a tutela inibitória é manejada para impedir a prática, a continuação ou a repetição do ilícito, e não uma tutela dirigida para a reparação do dano. Isso torna a tutela inibitória como

26 FIORILLO, Celso Antonio Pacheco. Curso de Direito Ambiental Brasileiro. 6. ed. São Paulo: Saraiva, 2005, p. 358.

27 MARINONI, Luiz Guilherme. Tutela específica: arts. 461, CPC e 84, CDC. 2. ed. São Paulo: Revista dos Tribunais, 2001. 
uma espécie de tutela jurisdicional voltada para o futuro, independentemente de estar sendo dirigida a impedir a prática, a continuação ou a repetição do ilícito.

Sobre a tutela ressarcitória, a despeito de ela não ser qualificada como tutela específica, não significa que deva ser excluída do âmbito das demandas ambientais; apenas deve ser classificada como tutela ambiental não específica. Até porque, pela tutela ressarcitória pelo viés monetário, poder-se-á obter a multa ambiental nos termos do artigo 13 da Lei no 7.347/1985. Além disso, a busca pela tutela específica, associada à ideia de fungibillidade da causa de pedir e do pedido, também não confina o julgamento ambiental aos estritos termos do pedido. Assim, o STJ afastou a tese de julgamento extra petita, como se vê do seguinte acórdão:

1. Na origem, cuida-se de agravo de instrumento interposto contra decisão do juízo de primeiro grau que deferiu pedido liminar requerido em Ação Civil Pública, cujo bojo fundamenta-se no dever da recorrente de promover o reflorestamento da mata ciliar em torno do reservatório da usina hidrelétrica de Salto Osório. 2. Consoante entendimento pacificado nesta Corte, o pedido inicial deve ser interpretado em consonância com a pretensão deduzida na exordial como um todo, levando em conta todos os fatos e fundamentos jurídicos presentes, de modo que o acolhimento da pretensão extraído da interpretação lógico-sistemática da peça inicial não implica julgamento extra petita. 3. In casu, relevante destacar que se trata de provimento liminar com vista à efetivação do pedido principal contido na Ação Civil Pública, qual seja, reflorestamento da mata ciliar, de modo que a determinação de que se promovam ações reflexas à sua efetivação não podem ser tomadas como julgamento extra petita ${ }^{28}$.

A elaboração da tutela específica pressupõe a criação judicial do direito. Para tanto, é preciso que haja a discricionariedade judicial fundando-se no ius edictio, mas que em nenhum momento isso signifique ilegalidade ou arbitrariedade.

Explica-se. Em situações em que se aplica o artigo 497 do CPC e/ou artigo 87 do CDC, o juiz terá o poder-dever de criar um modelo judicial de proteção do direito lesado/ameaçado. Há o dever de julgar; há o poder de julgar; mas a elaboração do conteúdo da decisão é livre para o juiz, eis que não há referência legislativa que estabeleça que lhe dê teor. Isso porque o direito normatizado não 


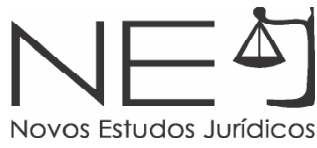

consegue chegar a tanta especificidade que os casos de degradação ambiental apresentam. Toma-se como exemplo o modo de como recuperar um corpo hídrico contaminado por metais pesados ou uma área que necessite de recomposição vegetal. No primeiro caso, será necessário estabelecer barreiras de contenção ou filtros de retenção; no segundo caso, será preciso definir a presença de árvores exóticas ou não com vista à recuperação da fauna também. Tais deliberações, reitera-se, depende do caso concreto e da orientação técnica que o juiz adotará na sentença. Não há norma legal regulamentadora a respeito. Portanto a figura do ius edictio é uma ferramenta de liberdade intelectual do juiz indispensável para a criação da tutela específica protetiva do meio ambiente. E para tanto invoca-se a discricionariedade judicial.Discricionariedade significa a liberdade de decidir e como decidir, porém se respeitando os limites legais mínimos e máximos da tomada de decisão e a legalidade da própria decisão em si. Portanto a primeira ideia acerca de discricionariedade judicial é de que ela atua entre parâmetros normativos, não podendo omitir a base mínima normativa, muito menos extrapolar os limites da lei.

A base mínima normativa serve de piso para a atuação jurisdicional, isto é, como minimamente deve-se comportar o juiz. No que se refere aos limites máximos, a rigor não há que se falar em discricionariedade judicial quando a decisão vai além do que é estabelecido por lei. É como se o paradigma normativo estabelecesse um "teto legal", fazendo prevalecer a ideia de que não pode o hermeneuta restringir o que a lei não restringe. É o que pronunciou o STJ: "Forçoso concluir que, nos casos em que a lei não fixa critério a ser obedecido na inflição da sanção, é defeso ao STJ invadir a discricionariedade judicial prevista em lei"29.

Mas vale uma advertência: não se pode confundir a discricionariedade judicial para elaborar a proteção jurisdicional do meio ambiente adequada ao caso concreto com a discricionariedade administrativa no trato da questão ambiental.

Acerca dessa segunda assertiva, vale lembrar que, em matéria ambiental, não há que se falar em discricionariedade administrativa se a respeito do conteúdo do ato houver lesão ou ameaça ao direito ao meio ambiente equilibrado ${ }^{30}$.

29 RESP n ${ }^{\circ}$ 664856/PR, $1^{\text {a }}$ T., rel. Min. Luiz Fux, j. 06/04/2006.

30 PAULA, Jônatas Luiz Moreira de. O Controle Judicial das Políticas Públicas Ambientais. In: Políticas Públicas

Ambientales. Alvaro Sánchez Bravo (editor). Sevilla: ArCiBel Editores S.L., 2008, p. 459-461. 
Há que se considerar a postura do artigo 225 da CF como um paradigma jurídico a impor à Administração Pública influência de respeitabilidade ambiental a uma série de condutas - comissivas e omissivas - que constituirão as políticas públicas.

Isso porque a citada norma constitucional é absolutamente clara, porque afirma categoricamente em seu caput que TODOS TÊM DIREITO AO MEIO AMBIENTE ECOLOGICAMENTE EQUILIBRADO, BEM COMUM DO POVO E ESSENCIAL À SADIA QUALIDADE DE VIDA, IMPONDO-SE AO PODER PÚBLICO E À COLETIVIDADE O DEVER DE DEFENDÊ-LO E PRESERVÁ-LO PARA AS PRESENTES E FUTURAS GERAÇÕES.

Daí que, ocorrendo ofensa ao direito ambiental, o ato administrativo sempre será ilegal, mesmo que a sua prática tenha ocorrida em oportuna discricionariedade, porque tal ato sempre estará a ofender a base normativa mínima, que é o artigo 225 da CF ou outras normas ambientais, inclusive as de caráter infralegal. Nesse sentido, em demanda que envolvia o serviço de coleta de lixo, decidiu o STJ a ponto de possibilitar a rediscussão de discricionariedade administrativa:

1. Resta estreme de dúvidas que a coleta de lixo constitui serviço essencial, imprescindível à manutenção da saúde pública, o que o torna submisso à regra da continuidade. Sua interrupção, ou ainda, a sua prestação de forma descontinuada, extrapola os limites da legalidade e afronta a cláusula pétrea de respeito à dignidade humana, porquanto o cidadão necessita utilizar-se desse serviço público, indispensável à sua vida em comunidade. 2. Releva notar que uma Constituição Federal é fruto da vontade política nacional, erigida mediante consulta das expectativas e das possibilidades do que se vai consagrar, por isso cogentes e eficazes suas promessas, sob pena de restarem vãs e frias enquanto letras mortas no papel. Ressoa inconcebível que direitos consagrados em normas menores como Circulares, Portarias, Medidas Provisórias, Leis Ordinárias tenham eficácia imediata e os direitos consagrados constitucionalmente, inspirados nos mais altos valores éticos e morais da nação sejam relegados a segundo plano. Trata-se de direito com normatividade mais do que suficiente, porquanto se define pelo dever, indicando o sujeito passivo, in casu, o Estado. 3. Em função do princípio da inafastabilidade consagrado constitucionalmente, a todo direito corresponde uma ação que o assegura, sendo certo que todos os cidadãos residentes em Cambuquira encartam-se na esfera desse direito, por isso a homogeneidade e transindividualidade do mesmo a ensejar a bem manejada ação civil pública. 4. A determinação judicial 


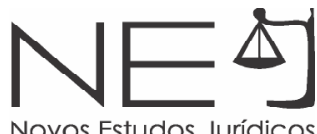

desse dever pelo Estado, não encerra suposta ingerência do judiciário na esfera da administração. Deveras, não há discricionariedade do administrador frente aos direitos consagrados, quiçá constitucionalmente. Nesse campo a atividade é vinculada sem admissão de qualquer exegese que vise afastar a garantia pétrea. 5. Um país cujo preâmbulo constitucional promete a disseminação das desigualdades e a proteção à dignidade humana, alçadas ao mesmo patamar da defesa da Federação e da República, não pode relegar a saúde pública a um plano diverso daquele que o coloca, como uma das mais belas e justas garantias constitucionais ${ }^{31}$.

A discricionariedade judicial é mecanismo indispensável para o alcance da tutela específica ou do resultado prático equivalente, necessário para a adequada proteção ambiental. Na Proposta de Anteprojeto de Lei da Nova Ação Civil Pública, está previsto no capítulo IV que, "na ação que tenha por objeto a imposição de conduta de fazer, de não fazer, pagar ou de entregar coisa, o juiz determinará a prestação ou a abstenção devida, bem como a cessação da atividade nociva, em prazo razoável, sob pena de cominação de medida subrogatória ou de indução, independentemente de requerimento do autor".

Já o Novo CPC determina no artigo 139, IV, que entre os poderes inerentes ao exercício da atividade jurisdicional, se encontra a possibilidade de o juiz determinar todas as medidas indutivas, coercitivas, mandamentais ou subrogatórias necessárias para assegurar o cumprimento de ordem judicial, inclusive nas ações que tenham por objeto prestação pecuniária.

Medidas indutivas devem ser consideradas como aquelas que visam ao cumprimento do ato no modo e na forma determinados; coercitivas são aquelas que visam cominar algum tipo de aflição à parte para que se cumpra o ato estabelecido; mandamentais são ordens impostas à parte para o específico cumprimento do ato, sob pena de incorrer em crime de desobediência; e subrogatórias são medidas que possam ser aplicadas a um terceiro, podendo o conteúdo dessa medida ser indutiva, coercitiva ou mandamental, ou ainda a possibilidade de fungibilidade de uma tutela por outra, seja para produzir a tutela específica, seja para produzir o resultado prático equivalente.

31 RESP n 575998/MG, $1^{\text {a }}$ CCiv., rel. Min. Luiz Fux, j. 07/10/2004 (negritou-se). 


\subsection{A RELATIVIZAÇÃO DA COISA JULGADA AMBIENTAL}

Por fim, há que se admitir a relativização da coisa julgada nas demandas ambientais em decorrência de vários motivos, a saber:

i. Incidência de direitos indisponíveis

As demandas que versem sobre indisponíveis permitem excepcionar a regra exposta, pelo fato de possibilitar a revisão de questões já debatidas num processo anterior. Cite-se como exemplo a demanda que discuta a guarda de menores, em que no artigo 35 do ECA-Estatuto da Criança e Adolescente estipulou-se que "a guarda poderá ser revogada a qualquer tempo, mediante ato judicial fundamentado, ouvido o Ministério Público".

Disposições semelhantes podem ser encontradas no Código Civil, que tratam da remoção do tutor (art. 1.766) ou do curador (art. 1.774). Nesses casos, observa-se que as questões que foram debatidas na demanda poderão ser renovadas em nova e futura ação. Assim, por exemplo, se um dos argumentos para definir a guarda do menor é a aptidão do réu em exercer tal encargo, na demanda posterior essa aptidão poderá ser revista.

Também pode ser arrolada como exemplo de inaplicabilidade do artigo 508 do CPC a regra do artigo 103 do CDC, ao tratar da coisa julgada secundum eventus litis. Informa o citado disposto consumerista que, na hipótese de improcedência do pedido por insuficiência de provas nas ações para tutela dos direitos coletivos ou difusos do consumidor, possibilita o legitimado propor a mesma ação - identidade de partes, causa de pedir e de pedido - desde que munido de novas provas.

Neste aspecto, urge diferenciar nova prova de prova nova. Será nova prova todo elemento probatório inédito que demonstra a veracidade da alegação. Será prova nova toda forma, inédita no processo, que contém elemento probatório não inédito em relação à lide. Assim, para diferenciar um do outro, basta atentar para o seguinte exemplo: numa ação em que se pleiteia a condenação da empresa-ré por dano ao consumidor em razão de ter lançado no mercado produto nocivo à saúde humana. O pedido da ação foi julgado improcedente porque o laudo pericial não soube precisar a nocividade do produto em razão da demora da 
realização desta prova. Se for ajuizada uma nova ação, tendo como elemento probatório prova testemunhal que conclua que a empresa-ré lançou no mercado o produto supostamente nocivo, estar-se-á diante de prova nova porque o elemento probatório contido nada acrescenta em relação ao anterior (a forma é nova, mas o conteúdo não). Porém, se for ajuizada outra ação, tendo o autor juntado um novo laudo pericial, muito mais apurado e avançado tecnologicamente, demonstrando a nocividade do produto a despeito da longevidade de tempo, estar-se-á diante de nova prova, posto que seu elemento probatório acrescenta em relação à prova anterior (é um elemento inédito e o conteúdo é novo). Assim, na primeira hipótese ficou desatendida a norma do artigo 103 do CDC, ao passo que a segunda hipótese demonstra que houve nova prova, possibilitando o ajuizamento de outra ação, nos termos do artigo 103 do CDC.

Interessante verificar que, nessa hipótese, a coisa julgada não ficou restrita à parte dispositiva da sentença, mas também atingiu a causa de pedir. Pois como a prova é o fundamento da existência da causa de pedir, se ficar constatado que se trata de nova prova, a segunda demanda será processada; por outro lado, caso ficar constatado que se trata de prova nova, a segunda demanda deverá ser extinta, por verificar-se a ocorrência da coisa julgada.

\section{ii. Descoberta de novos métodos científicos}

Uma situação que já vem ocorrendo no direito brasileiro e para qual não se pode fechar os olhos é a descoberta de novos métodos científicos que estão a demonstrar o equívoco de algumas decisões judiciais.

Os casos mais comuns ocorreram nas ações de investigação de paternidade, cuja sentença transitada em julgado apoiou-se em exame de tipagem sanguínea pelos sistemas hemáceos e leucócitos, utilizando-se geralmente dos métodos $A B O$ e HLA. Posteriormente, em exame de DNA realizado extrajudicialmente, verifica-se a inexistência da relação de paternidade, o que propicia a ação negatória de paternidade.

Também admissível a mitigação da coisa julgada na hipótese do pedido de investigação ter sido julgado improcedente em razão da precariedade de provas, mas que, motivado por uma nova ação fundada em exame de DNA apontando o reconhecimento da paternidade. 
Observe-se que a coisa julgada se formou em torno de um ato de convicção do juiz ao fundamentar a sentença num elemento probatório precário, que apenas se destinava a justificar a tese da defesa: exclusão do réu do grupo dos supostos pais da criança. Em vista do resultado deste exame ser contrário aos interesses do réu, sentiu-se autorizado o Poder Judiciário em proceder à pretensão, o que se mostra equivocado, porque o fato constitutivo do direito do autor não se mostrou ainda provado, mas tão somente não comprovada a tese da defesa.

Por isso que, corretamente, a jurisprudência vinha mitigando a coisa julgada ante a inovação científica que as novidades tecnológicas. Tudo isso em nome da verdade real. É o que se pode observar dos seguintes acórdãos:

PATERNIDADE - RECONHECIMENTO - NEGATIVA PROVADA POSTERIORMENTEPORDNA-COISAJULGADA-INADMISSIBILIDADE. Afasta-se a alegação de coisa julgada, para ser admitida a ação de negativa de paternidade, quando o autor comprova com a inicial, através do moderno exame de DNA, não ser o pai biológico da requerida, conforme reconhecido anteriormente em ação de investigação de paternidade"32. "Processo civil. Investigação de Paternidade. Repetição de ação anteriormente ajuizada, que teve seu pedido julgado improcedente por falta de provas. Coisa julgada. Mitigação. Doutrina. Precedentes. Direito de família. Evolução. Recurso acolhido. I - Não excluída expressamente a paternidade do investigado na primitiva ação de investigação de paternidade, diante da precariedade da prova e da ausência de indícios suficientes a caracterizar tanto a paternidade como a sua negativa, e considerando que, quando do ajuizamento da primeira ação, o exame pelo DNA ainda não era disponível e nem havia notoriedade a seu respeito, admite-se o ajuizamento de ação investigatória, ainda que tenha sido aforada uma anterior com sentença julgando improcedente o pedido. II - Nos termos da orientação da turma, 'sempre recomendável a realização de perícia para investigação genética (HLA e DNA), porque permite ao julgador um juízo de fortíssima probabilidade, senão de certeza' na composição do conflito. Ademais, o progresso da ciência jurídica, em matéria de prova, está na substituição da verdade ficta pela verdade real. III - A coisa julgada, em se tratando de ações de estado, como no caso de investigação de paternidade, deve ser interpretada modus in rebus. Nas palavras de respeitável e avançada doutrina, quando estudiosos hoje se aprofundam no reestudo do instituto, na busca sobretudo da realização do processo justo, 'a coisa julgada existe como criação necessária à segurança prática das relações jurídicas e as dificuldades que se opõem à sua ruptura se explicam pela mesmíssima razão. Não se pode olvidar, todavia, que numa sociedade de homens livres, a justiça tem de estar acima da segurança, porque sem justiça não há liberdade'. IV - Este tribunal

32 TJGO, Agr. n 8.938-8/180, $3^{\text {a }}$ CCiv., rel. Des. Charife Oscar Abrão, j.21/09/1995. 


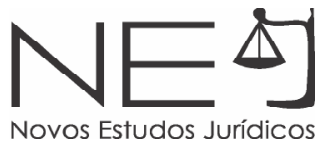

tem buscado, em sua jurisprudência, firmar posições que atendam aos fins sociais do processo e às exigências do bem comum ${ }^{33}$.

Por outro lado, divergiu o STJ ao compreender que:

Ação de negativa de paternidade. Exame pelo DNA posterior ao processo de investigação de paternidade. Coisa julgada. 1. Seria terrificante para o exercício da jurisdição que fosse abandonada a regra absoluta da coisa julgada que confere ao processo judicial força para garantir a convivência social, dirimindo os conflitos existentes. Se, fora dos casos nos quais a própria lei retira a força da coisa julgada, pudesse o magistrado abrir as comportas dos feitos já julgados para rever as decisões não haveria como vencer o caos social que se instalaria. A regra do art. 468 do Código de Processo Civil $^{34}$ é libertadora. Ela assegura que o exercício da jurisdição completa-se com o último julgado, que se torna inatingível, insuscetível de modificação. E a sabedoria do Código é revelada pelas amplas possibilidades recursais e, até mesmo, pela abertura da via rescisória naqueles casos precisos que estão elencados no art. 485. 2. Assim, a existência de um exame pelo DNA posterior ao feito já julgado, com decisão transitada em julgado, reconhecendo a paternidade, não tem o condão de reabrir a questão com uma declaratória para negar a paternidade, sendo certo que o julgado está coberto pela certeza jurídica conferida pela coisa julgada. 3. Recurso especial conhecido e provido ${ }^{35}$.

Em vista disso, observa-se que o mito da coisa julgada está sob discussão, uma vez que o processo civil tem por mira a transformação social, e a coisa julgada, que surge como garantia, deve estar aliada à concepção transformista do processo.

iii. A relativização da coisa julgada em demandas ambientais

Na sequência, pode-se observar a relativização da coisa julgada em matéria ambiental em virtude de descoberta científica ou por inovação técnica. A inovação tecnológica pode gerar uma situação de desequilíbrio nos padrões ambientais, a ponto de, em nome do Princípio de Prevenção, restringir o seu uso ou admitir sua utilização mediante condições ambientais corretivas. Já a novidade científica permite que os avanços na ciência determinem com clareza se determinada atividade econômica é poluente ou degradante. Assim, em nome do Princípio da Prevenção e pelo novo conhecimento que se adquiriu

33 STJ, RESP n 226436/PR, $4^{\text {a }}$ T., rel. Min. Sálvio de Figueiredo Teixeira, j. 28/06/2001.

34 Refere-se ao art. 468 do CPC revogado, que continha a seguinte redação: Art. 468. A sentença, que julgar total ou parcialmente a lide, tem força de lei nos limites da lide e das questões decididas". 
Novos Estudos Jurídicos

pela novidade científica, a atividade econômica que se desenvolve deverá condicionar-se a padrões ambientais. Em tais casos, é possível, em tese, de que tais questões já tivesse sido objeto de lide e sobre ela produziu-se coisa julgada. Mencionam-se, a título de exemplo, casos como o uso de antenas para a telefonia e das sementes transgênicas.

Pois bem, há que se considerar que, em virtude de inovação tecnológica ou novidade científica, reconheça-se a nocividade de uma atividade econômica pelo mais variado motivo (como aconteceu recentemente com as gorduras trans) como elemento preponderante para fundamentar uma ação ambiental e condicionar o exercício dessa atividade econômica aos padrões ambientais aceitáveis. Neste aspecto, a eventual existência de coisa julgada material há que ser afastada para ser admitido o novo conhecimento técnico-científico produzido.

Esta tese encontra sustentação em Elaine Harzheim Macedo, ao propor dois paradigmas para a relativização ambiental: a) que se tenha uma sentença voltada especialmente para o futuro, ou seja, que ao regular os danos ambientais, que não o faça voltado exclusivamente para os fatos pretéritos, mas também para conferir ênfase às medidas inibitórias e executivas de tutela do meio ambiente; b) que tais julgamentos sejam mutáveis, modificáveis conforme a necessidade/ exigibilidade das circunstâncias fáticas, a fim de propor soluções alternativas ou permitir que se tenham alternativas ao longo do tempo a ponto de permitir que sejam efetivadas nos próprios autos ${ }^{36}$.

Em vista disso, observa-se que o mito da coisa julgada está sob discussão, uma vez que o processo civil tem por mira a transformação social, e a coisa julgada, que surge como garantia, deve estar aliada à concepção transformista do processo.

Assim, como o empreendimento deve estar permanentemente ajustado a uma situação ambiental adequada aos padrões ambientais, então se verifica que qualquer modificação no padrão ambiental - seja no âmbito regulatório pela autoridade ambiental, seja pelo empreendedor - se torna passível de rediscussão a qualquer lide já anteriormente julgada.

36 MACEDO, Elaine Harzheim. Relativização da coisa julgada em matéria ambiental. In: Revista de Direito Ambiental. Volume 42. Ano 11. Abril-Junho 2006. São Paulo: Revista dos Tribunais, 2006, p. 74. 
Nesse compasso, há que se admitir a relativização da coisa julgada quando, em vista de descoberta científica ou inovação de técnicas, se constatar ameaças ou agressões ao equilíbrio e sadio do meio ambiente em virtude de modificações nos padrões ambientais.

Não à toa que o STJ pronunciou expressamente que:

(...) A Segunda Turma desta Corte firmou a orientação de inaplicabilidade de norma ambiental superveniente de cunho material aos processos em curso, seja para proteger o ato jurídico perfeito, os direitos ambientais adquiridos e a coisa julgada, seja para evitar a redução do patamar de proteção de ecossistemas frágeis sem as necessárias compensações ambientais $(. . .)^{37}$.

Observa-se, pois, a possibilidade de se admitir a relativização da coisa julgada em demandas ambientais dada a natureza indisponível do conteúdo da norma jurídica e da descoberta de novos métodos científicos.

\section{CONSIDERAÇÕES FINAIS}

Em vista do exposto, urge a necessidade de se construir um conjunto de regras e diretivas necessárias para a melhor e adequada proteção jurisdicional do meio ambiente. Acredita-se que o estabelecimento de uma Máxima Proteção Jurisdicional do Meio Ambiente possa permitir tal intento quando se aplicam as técnicas apresentadas ao longo do texto.

\section{REFERÊNCIAS DAS FONTES CITADAS}

BOSSELMANN, Klaus. The Principle of Sustainability: Transforming Law and Governance. Hampshire, England: Ashgate, 2008.

PIASSA, Felipe José e DIAS, Bruno Smolarek. Influências pós-positivistas ao novo direito constitucional e o fenômeno da constitucionalização do direito. Revista Eletrônica Direito e Política, Programa de Pós-Graduação Stricto Sensu em Ciência Jurídica da UNIVALI, Itajaí, v.10, n.3, $2^{\circ}$ quadrimestre de 2015. Disponível em: www.univali.br/direitoepolitica - ISSN 1980-7791. 
DIAS, Bruno Smolarek; MARDEGAN, Herick. Sustentabilidade como fundamento da cidadania transnacional. Revista Eletrônica Direito e Política, Programa de Pós-Graduação Stricto Sensu em Ciência Jurídica da UNIVALI, Itajaí, v.6, n.2, $2^{\circ}$ quadrimestre de 2011. Disponível em: www.univali.br/direitoepolitica - ISSN 1980-7791

FIORILlO, Celso Antonio Pacheco. Curso de Direito Ambiental Brasileiro. 6a edição. São Paulo: Saraiva, 2005.

MACEDO, Elaine Harzheim. Relativização da coisa julgada em matéria ambiental. In: Revista de Direito Ambiental. Volume 42. Ano 11. Abril-Junho 2006. São Paulo: Revista dos Tribunais, 2006.

MARINONI, Luiz Guilherme. Tutela específica: arts. 461, CPC e 84, CDC. 2. ed. São Paulo: Revista dos Tribunais, 2001.

PAULA, Jônatas Luiz Moreira de. Aspectos da tutela individual ambiental. Revista de Processo. Volume 145. Ano 32. Março 2007. São Paulo: Revista dos Tribunais, 2007.

O Devido Processo Legal Ambiental. In: Direito Ambiental e Cidadania. Jônatas Luiz Moreira de Paula (coord.). Leme: JH Mizuno, 2007.

O Controle Judicial das Políticas Públicas Ambientais. In: Políticas Públicas Ambientales. Alvaro Sánchez Bravo (editor). Sevilla: ArCiBel Editores S.L., 2008.

RODRIGUES, Marcelo Abelha. Processo Civil Ambiental. São Paulo: Revista dos Tribunais, 2008.

Recebido em: 30/10/2018

Aprovado em: 04/04/2019 